\title{
Ash Particle Behaviors during Combustion and Gasification of Coke
}

\author{
Yasuaki UEKI, ${ }^{1) *}$ Koki TESHIMA, ${ }^{2)}$ Ryo YOSHIIE ${ }^{2)}$ and Ichiro NARUSE ${ }^{1)}$ \\ 1) Institute of Materials and Systems for Sustainability, Nagoya University, Furo-cho, Chikusa-ku, Nagoya, 464-8603 Japan. \\ 2) Department of Mechanical Systems Engineering, Nagoya University, Furo-cho, Chikusa-ku, Nagoya, $464-8603$ Japan.
}

(Received on October 29, 2019; accepted on January 14, 2020)

\begin{abstract}
A significant amount of $\mathrm{CO}_{2}$ gas is emitted from blast furnaces in ironmaking processes because large amounts of coke and pulverized coal are consumed as the reducing agent and heat source. Accordingly, $\mathrm{CO}_{2}$ emissions from blast furnaces should be reduced to control global warming. One promising method to achieve the $\mathrm{CO}_{2}$ reduction involves decreasing the reducing agent rate (RAR) during blast furnace operation. However, fine particles such as ash, derived from coke and pulverized coal, may affect the permeability in the furnace under low RAR operation. Therefore, the behavior of ash particles in a coke lump during combustion and gasification was elucidated experimentally in this work. Combustion and gasification experiments on a single coke lump were conducted in air and in a $\mathrm{CO}-\mathrm{CO}_{2}$ gas mixture atmosphere at temperatures from 1473 to $1673 \mathrm{~K}$. The ash particles in the coke lump were observed using a scanning electron microscope (SEM). Many large ash particles were observed near the surface of the coke lump during combustion. This is because the ash particles coalesced with the neighboring ash particles near the surface. Only molten fine ash particles were formed during gasification. This difference in the ash behavior during combustion from gasification will depend on the consumption behavior of the carbonaceous matrix.
\end{abstract}

KEY WORDS: coke; ash particle; combustion; gasification; blast furnace.

\section{Introduction}

$\mathrm{CO}_{2}$ emissions from steel industries constitute approximately $15 \%$ of the total emissions in Japan. ${ }^{1)}$ In particular, $\mathrm{CO}_{2}$ emissions from iron making processes, such as blast furnaces, coke ovens, and sintering machines, account for about $70 \%$ of all steel industry emissions, ${ }^{2}$ as they use large amounts of carbonaceous materials including coke and pulverized coal. These carbonaceous materials play an essential role in supplying heat and taking part in the reduction and carburization reactions. In addition, the coke plays a role of a spacer for keeping permeability in blast furnaces. ${ }^{3)}$ Accordingly, reduction of $\mathrm{CO}_{2}$ emissions from blast furnaces is an urgent requirement to combat global warming. A promising method for achieving this is to operate blast furnaces at low reducing agent rate (RAR). ${ }^{7}$ However, under a low RAR operation, the thickness of the coke layer decreases and the thickness of the ore layer increases. This decrease of the coke causes an increase of pressure drop in blast furnaces. ${ }^{47}$ ) Therefore, these changes negatively impact permeability, which is important for stable operation of the furnace.

Fine ash particles, derived from coke and pulverized coal, can also affect the permeability in the furnace under low RAR operation. In the cohesive and dripping zone, ash

* Corresponding author: E-mail: yasuaki.ueki@mae.nagoya-u.ac.jp DOI: https://doi.org/10.2355/isijinternational.ISIJINT-2019-692 particles at the surface of the coke prevent contact between the liquid (molten iron, molten slag) and coke. Moreover, the ash particles react with the liquid. These cause a change in liquid properties (viscosity, wettability, etc.). ${ }^{8-16)}$ This change affects the liquid and gas permeability in the cohesive and dripping zone. Additionally, a shell layer derived from the ashes of coke and pulverized coal may be formed in the depths of the raceway in the blast furnace. This shell layer causes accumulation of fine particles on the deadman surface and the formation of a local flood of droplets, which can affect the permeability in lower parts of the blast furnace. ${ }^{17,18)}$

Many authors have studied the melting behavior of coal ash prepared at temperatures between $1023-1088 \mathrm{~K}$ in reducing and oxidizing atmospheres by using ash-fusion temperature (AFT) tests. ${ }^{19-21)}$ The results of AFT tests show that the bulk melting behavior of coal ash is different from the melting behavior of ash particles during combustion (reaction in Air) and gasification (reaction in $\mathrm{CO}-\mathrm{CO}_{2}$ mixtures). In addition, some works have investigated the melting behavior of ash in coal particles (coal particle size: 550 $\mu \mathrm{m}$ ) during combustion and gasification. ${ }^{22-26)}$ However, the behavior of ash particles in coke lumps during combustion and gasification has not been elucidated so far.

In this work, the behavior of ash particles in a coke lump with a diameter of approximately $17 \mathrm{~mm}$ during combustion and gasification was analyzed experimentally. Combustion and gasification experiments were conducted on a single 
coke lump in gas atmospheres of air and $\mathrm{CO}-\mathrm{CO}_{2}$ mixtures. The ash particles in the coke lump were observed by using a scanning electron microscope (SEM). The effects of atmospheric gas and temperature on the behavior of the ash particles in the coke lump were investigated in detail.

\section{Experimental Procedure}

\subsection{Experimental Sample}

Table 1 shows the properties of the coke lump samples used in this study. The average diameter and porosity of the coke samples were $17 \mathrm{~mm}$ and $31 \%$, respectively. Table 2 shows the ash composition in the coke lump tested. Table 3 lists the melting properties (following the JIS M8801 method) of ash. The melting points (hemispherical temperature) of ash were $1758 \mathrm{~K}$ in an oxidizing atmosphere and $1708 \mathrm{~K}$ in a reducing atmosphere. The JIS M8 801 method is used to determine the fusibility of ash.

\subsection{Experimental Method}

Coke combustion and gasification experiments were conducted using an electrically heated vertical tube furnace, as shown in Fig. 1. A Pt sample basket, which was suspended by a Pt wire, was connected to an electronic balance. $\mathrm{N}_{2}$ gas was introduced at a flow rate of $6.66 \times 10^{-5} \mathrm{~m}^{3} / \mathrm{s}$ into a reaction tube (alumina tube, ID: $60 \mathrm{~mm}$ ). When the furnace temperature reached the experimental condition, the furnace was moved up instantaneously and the sample was placed in an isothermal zone. The coke sample was held at

Table 1. Properties of the coke lump samples.

\begin{tabular}{cr}
\hline Proximate analysis [wt $\%$, dry basis] \\
\hline Volatile matter & 1.7 \\
Fixed carbon & 87.0 \\
Ash & 11.3 \\
\hline
\end{tabular}

Table 2. Ash composition in the coke.

\begin{tabular}{cr}
\hline Ash composition $[w t \%]$ \\
$\mathrm{SiO}_{2}$ & 49.57 \\
$\mathrm{Al}_{2} \mathrm{O}_{3}$ & 27.37 \\
$\mathrm{Fe}_{2} \mathrm{O}_{3}$ & 11.21 \\
$\mathrm{CaO}$ & 2.69 \\
$\mathrm{MgO}$ & 0.99 \\
$\mathrm{Na}_{2} \mathrm{O}$ & 0.51 \\
$\mathrm{~K}_{2} \mathrm{O}$ & 1.50 \\
$\mathrm{SO}_{3}$ & 1.13 \\
\hline
\end{tabular}

Table 3. Melting properties of ash.

\begin{tabular}{ccc}
\hline & $\begin{array}{c}\text { Oxidizing } \\
\text { atmosphere }\end{array}$ & $\begin{array}{c}\text { Reducing } \\
\text { atmosphere }\end{array}$ \\
\hline Softening temperature $[\mathrm{K}]$ & 1603 & 1548 \\
Hemispherical temperature $[\mathrm{K}]$ & 1758 & 1708 \\
Fluid temperature $[\mathrm{K}]$ & 1783 & 1758 \\
\hline
\end{tabular}

the experimental temperature under a $\mathrm{N}_{2}$ gas atmosphere in order to remove most volatile matter (VM). The $\mathrm{N}_{2}$ gas was then replaced with either air or $\mathrm{CO}-\mathrm{CO}_{2}$ mixture gas, to initiate combustion or gasification of the coke sample. The weight loss of the coke sample was measured continuously by an electronic balance. When the weight loss of the sample reached the target value, the furnace was refilled with $\mathrm{N}_{2}$ gas and the sample was rapidly cooled in $\mathrm{N}_{2}$ gas flow. Table 4 shows the experimental conditions.

\subsection{Calculation of Reaction Ratio and Shrinkage Ratio of the Coke Samples}

The progress of the combustion and gasification reactions of the coke samples was evaluated by the reaction ratio, according to Eq. (1).

$$
X=\Delta W / W_{F C} \times 100
$$

where $X[\%]$ is the reaction ratio, $\Delta W[\mathrm{~g}]$ is the weight loss of the coke sample after the removal of VM in the combustion experiment or in the gasification experiment, and $W_{F C}$ [g] is the weight of fixed carbon (FC) in the coke sample.

The shrinkage ratio of the coke sample was calculated according to Eq. (2).

$$
\text { Shrinkage ratio }=\left(d_{0}-d\right) / d_{0} \times 100
$$

where $d_{0}[\mathrm{~m}]$ is the initial diameter of the coke sample and $d$ $[\mathrm{m}]$ is the diameter of the coke sample after the experiment.

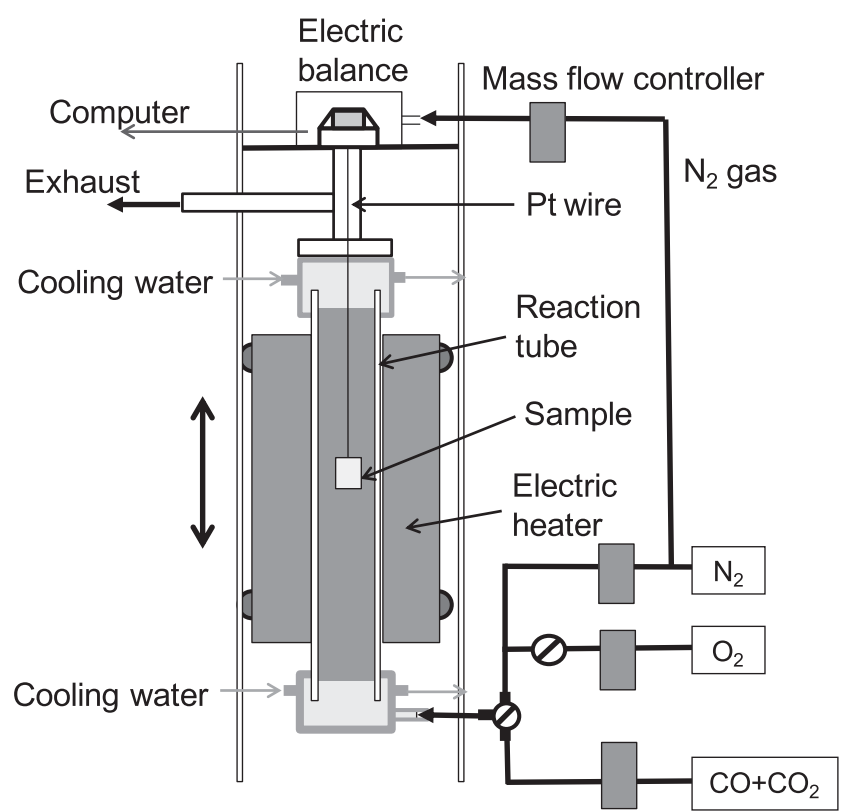

Fig. 1. Schematic of the electrically heated vertical tube furnace for coke combustion and gasification experiments.

Table 4. Experimental conditions.

\begin{tabular}{ccc}
\hline Conditions & Combustion & Gasification \\
\hline Atmospheres $[\mathrm{vol} \%]$ & Air & $\mathrm{CO}: \mathrm{CO}_{2}=75: 25$, \\
$50: 50,75: 25,0: 100$ \\
Gas flow rate $\left[\mathrm{L}_{\mathrm{N}} / \mathrm{min}\right]$ & 4.0 \\
Furnace temperatures $[\mathrm{K}]$ & $1473,1573,1673$ \\
Reaction ratios $[\%]$ & $50,80,100$ \\
\hline
\end{tabular}



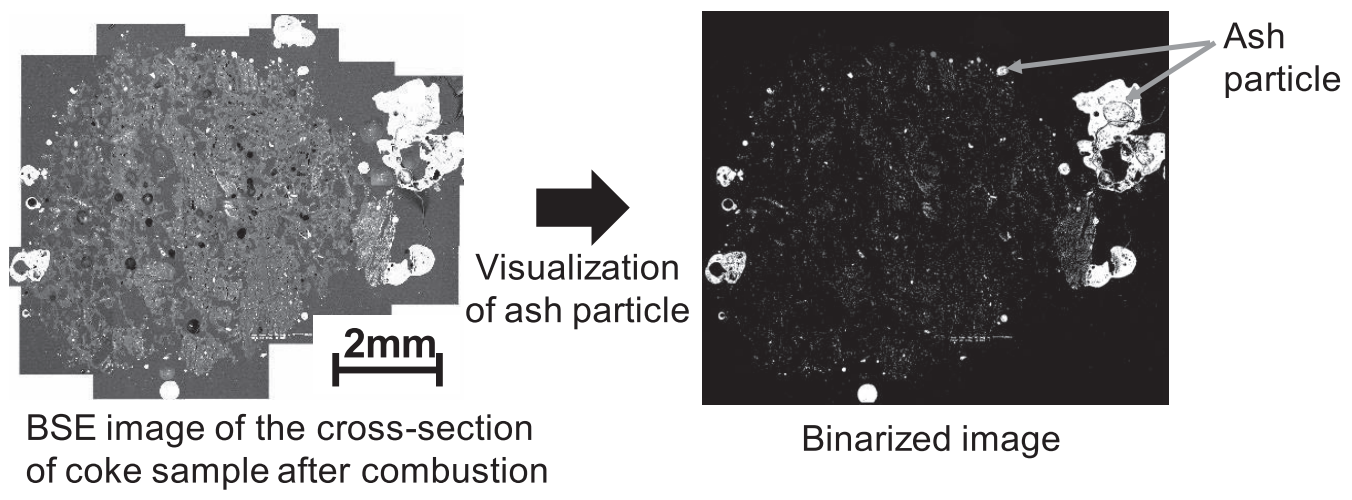

Binarized image

Fig. 2. BSE image and binarized image of the cross-section of the coke sample after combustion.

\subsection{Measurement Method for Sizes of Ash Particles and Porosity of the Coke Sample}

The coke samples (reaction ratio of $80 \%$ ) obtained by the experiments were buried in a resin, cut horizontally, and polished. Then, cross-sections of the coke samples were observed using an SEM. In order to quantitatively evaluate the sizes of the ash particles, individual particle diameters were measured by image analysis. Back-scattered electron (BSE) images were binarized to distinguish the ash particles from the carbonaceous matrix and resin by using particle analysis software (ImageJ). As an example, BSE and binarized images are shown in Fig. 2. The white part indicates ash in the binarized image. The ash particles were assumed to be spherical, and the diameter of individual ash particles was determined from the area they occupied. Ash particles with a diameter more than $22 \mu \mathrm{m}$ could be measured because of the resolution of the images. In this work, the volume of ash particles with a diameter less than $22 \mu \mathrm{m}$ did not affect the total volume of ash particles. Additionally, the porosity of the coke sample was measured using a similar method.

\section{Results and Discussion}

\subsection{Reaction Ratios for the Combustion and the Gasification Experiments}

Figure 3 shows the curves of the reaction ratios for the combustion experiment and the gasification experiment at $1673 \mathrm{~K}$. The reaction ratios reached $80 \%$ at $1000 \mathrm{~s}$ and $2900 \mathrm{~s}$ in the combustion and the gasification $\left(\mathrm{CO}: \mathrm{CO}_{2}=\right.$ 50:50) experiments, respectively. It takes longer for a coke sample to arrive at the same reaction ratio under the gasification condition, so the gasification reaction rate of coke at $1673 \mathrm{~K}$ is lower than the combustion reaction rate at the same temperature. ${ }^{17,18)}$ For the gasification condition, the gasification reaction rate increased with an increase in the volume ratio of $\mathrm{CO}_{2}$ gas in the atmosphere.

Figure 4 shows the curves of the reaction ratios for the combustion experiment and the gasification experiment $\left(\mathrm{CO}: \mathrm{CO}_{2}=50: 50\right)$ at different temperatures. The combustion reaction rate depended very little on the experimental temperature in the range of experimental temperatures investigated in this study. In addition, the gasification reaction rate indicated temperature dependence.

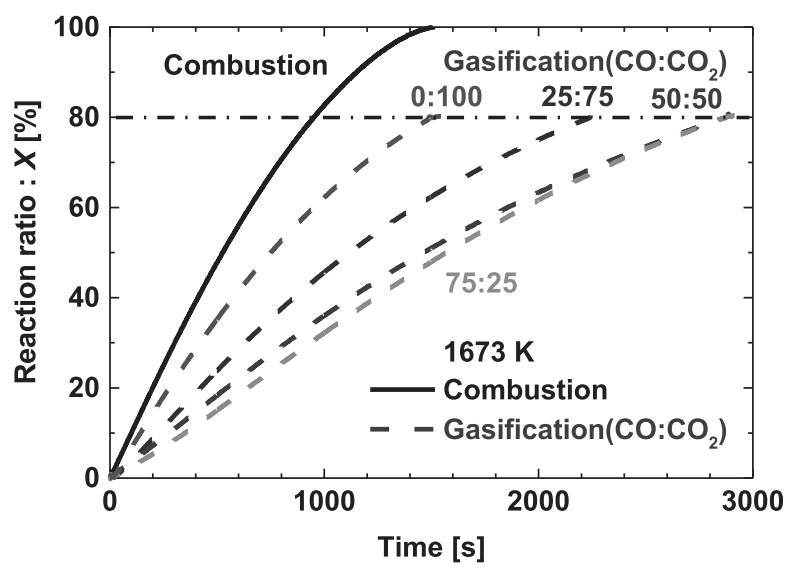

Fig. 3. Curves of the reaction ratios for the combustion and the gasification experiments at $1673 \mathrm{~K}$.

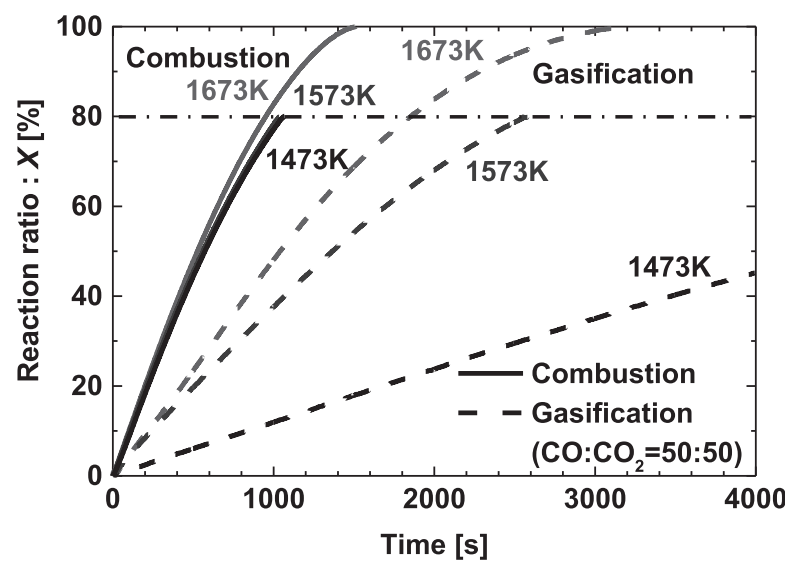

Fig. 4. Curves of the reaction ratios for the combustion and the gasification experiments at different temperatures.

\subsection{Changes in the Coke Sample during Combustion and Gasification}

Figure 5 shows external images of raw coke and cokes during combustion and gasification $\left(\mathrm{CO}: \mathrm{CO}_{2}=50: 50\right)$ at $1673 \mathrm{~K}$. One can see that during combustion, the coke sample becomes much smaller in size. In addition, spherical ash particles adhere to the surface of the coke sample. In contrast, during gasification, the coke sample becomes only slightly smaller in size and its external appearance hardly changes.

Figure 6 shows BSE images of the cross-sections in the vicinity of the surface of the raw coke sample and of the 


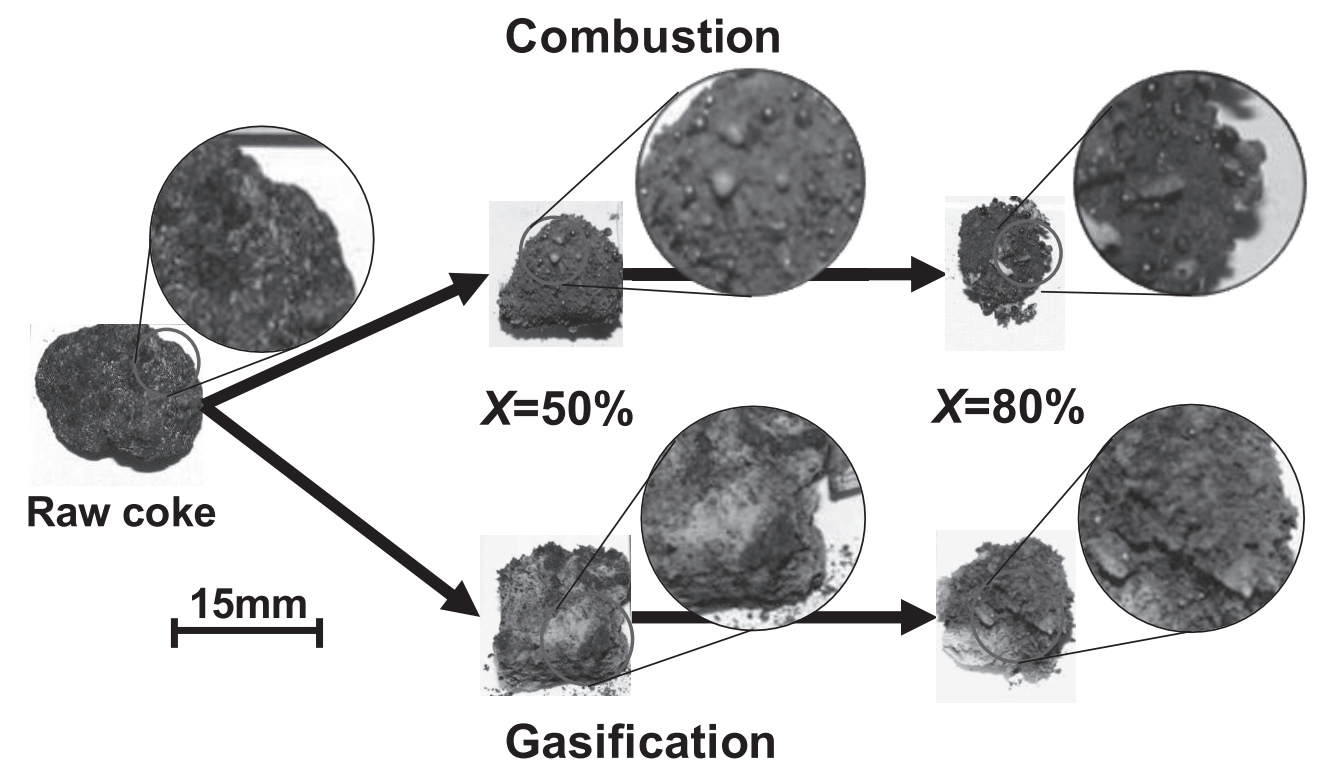

Fig. 5. External images of raw coke and coke during combustion and gasification $\left(\mathrm{CO}: \mathrm{CO}_{2}=50: 50\right)$ at $1673 \mathrm{~K}$.
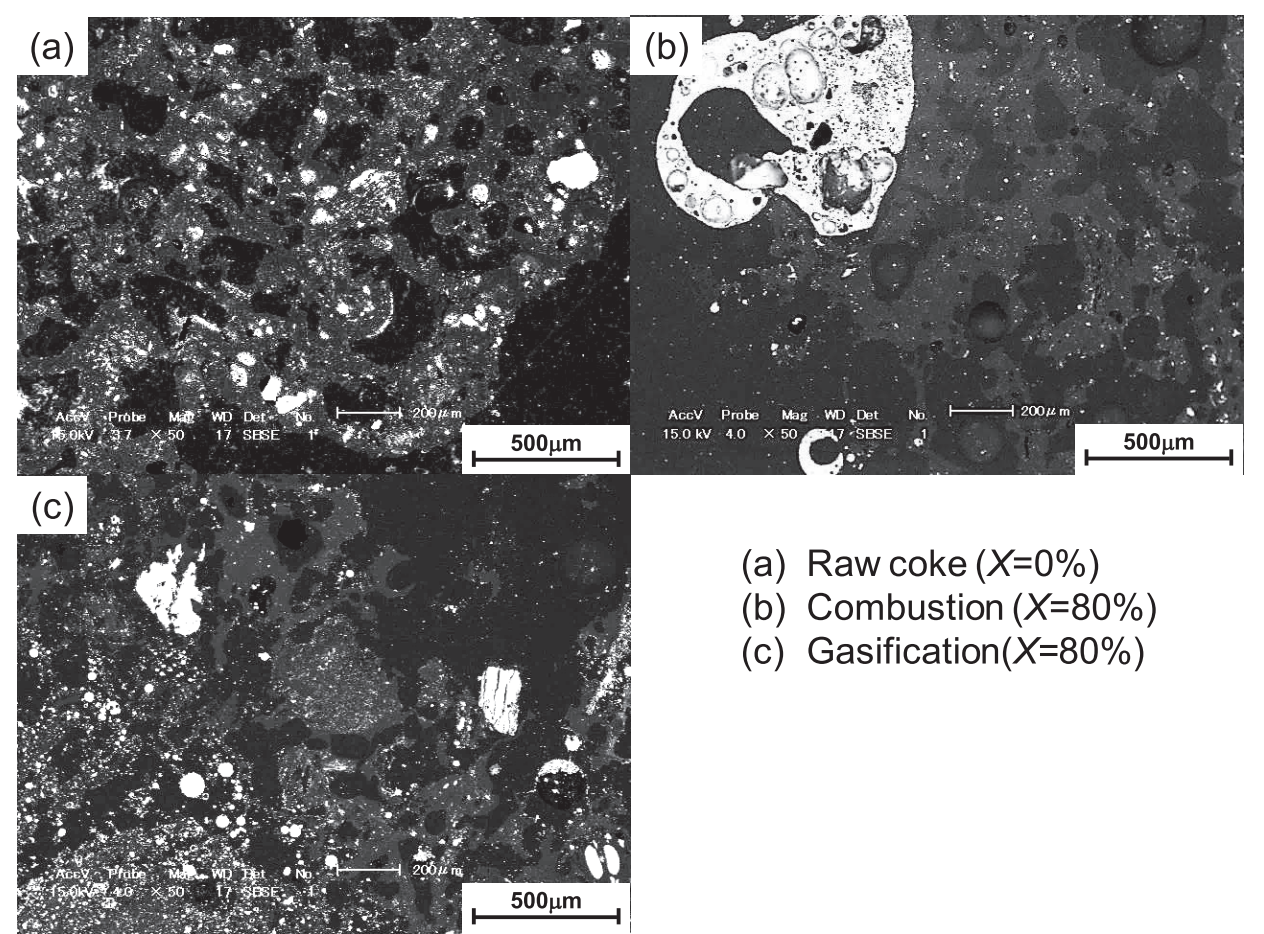
(a) Raw coke $(X=0 \%)$
(b) Combustion $(X=80 \%)$
(c) Gasification $(X=80 \%)$

Fig. 6. BSE images of cross-sections in the vicinity of the surface of the raw coke sample and of coke samples (reaction ratio of $80 \%)$ after combustion and gasification $\left(\mathrm{CO}: \mathrm{CO}_{2}=50: 50\right)$ at $1673 \mathrm{~K}$.

coke samples (reaction ratio of $80 \%$ ) after combustion and gasification $\left(\mathrm{CO}: \mathrm{CO}_{2}=50: 50\right)$ at $1673 \mathrm{~K}$. The white, light gray, and dark gray (black) parts indicate the ash particles, carbonaceous matrices, and resin, respectively. For the raw coke sample, ash particles of various particle sizes are interspersed in the carbonaceous matrix. Molten spherical ash particles cannot be observed in the raw coke sample. The spherical ash particle which did not have a corner was judged the molten ash particle. In contrast, the coke sample after the combustion experiment displays many large molten ash particles at its surface. However, the coke sample under the gasification condition does not have molten large ash particles inside the coke sample. Moreover, some molten spherical fine ash particles exist inside the sample. From these results, one can see that the size of the ash particles in the coke samples differs in the two reactions.

\subsection{Volume Fractions of Different-sized Ash Particles during Combustion and Gasification}

Figure 7 shows the volume fractions of ash particles with different particle sizes for the raw coke sample and the coke samples (reaction ratio of $80 \%$ ) after the combustion and gasification $\left(\mathrm{CO}: \mathrm{CO}_{2}=50: 50\right)$ experiments at $1673 \mathrm{~K}$. Only the volume fraction of the ash particles with diameters greater than $100 \mu \mathrm{m}$ shows an error bar. From this figure, for the coke sample with a reaction conversion of $80 \%$ after the combustion experiment, the volume fraction of ash particles with diameters greater than $100 \mu \mathrm{m}$ becomes drasti- 
cally larger than that for the raw coke sample. This result indicates that ash particles coalesce during combustion. In contrast, the volume fraction of ash particles with diameters greater than $100 \mu \mathrm{m}$ in the coke sample after gasification, with a reaction conversion of $80 \%$, only becomes slightly larger than that for the raw coke sample.

Figure 8 shows the volume fractions of different-sized ash particles for the raw coke sample and the coke samples (reaction ratio of $80 \%$ ) after the gasification experiments under $\mathrm{CO}-\mathrm{CO}_{2}$ mixture gas at $1673 \mathrm{~K}$. Only the volume fraction of the ash particles with diameter more than 100 $\mu \mathrm{m}$ for the raw coke sample and the coke samples after the gasification experiments under $50 \% \mathrm{CO}-50 \% \mathrm{CO}_{2}$ atmosphere shows an error bar. The volume fractions of the various ash particle sizes in the coke sample after gasification under $75 \% \mathrm{CO}-25 \% \mathrm{CO}_{2}$ atmosphere were similar to those of the raw coke sample. The volume fraction of ash particles with diameter more than $100 \mu \mathrm{m}$ increased with the increase in the volume ratio of $\mathrm{CO}_{2}$ in atmosphere gas. As with the coke samples after combustion, this is because the coalescence of ash particles in the coke samples occurs during the gasification reaction. However, the degree of ash particle coalescence during the gasification reaction is not as great as for the combustion reaction.

The effect of the experimental temperature on the volume fractions of different-sized ash particles for the coke samples

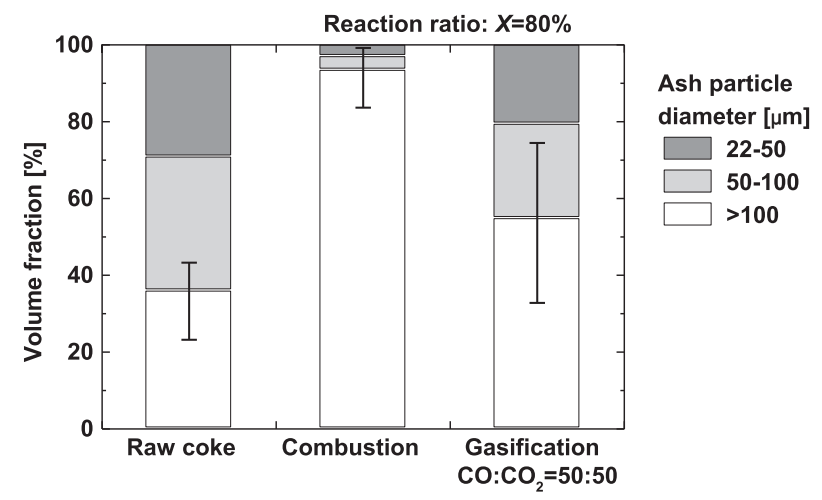

Fig. 7. Volume fraction of different-sized ash particles for the raw coke sample and the coke samples (reaction ratio of $80 \%$ ) after combustion and gasification $\left(\mathrm{CO}: \mathrm{CO}_{2}=50: 50\right)$ at $1673 \mathrm{~K}$.

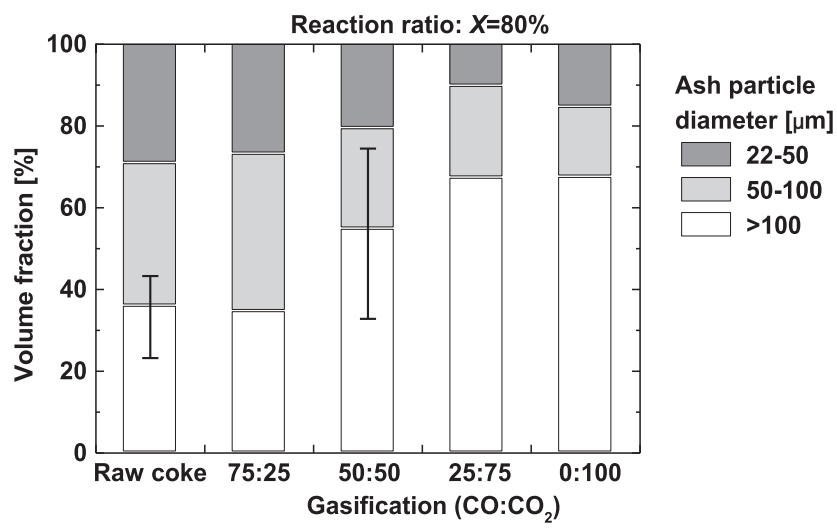

Fig. 8. Volume fraction of different-sized ash particles for the raw coke sample and the coke samples (reaction ratio of $80 \%$ ) after the gasification experiments under $\mathrm{CO}-\mathrm{CO}_{2}$ mixture gas at $1673 \mathrm{~K}$. (reaction ratio of $80 \%$ ) after the combustion and the gasification $\left(\mathrm{CO}: \mathrm{CO}_{2}=50: 50\right)$ experiments are shown in Figs. 9 and 10, respectively. For both reactions, the volume fraction of the ash particles with diameter more than $100 \mu \mathrm{m}$ increased with an increase in the experimental temperature. It is guessed that this is because the coalescence of ash particles was promoted due to the increase in temperature. In addition, the temperature dependence of the ash particle coalescence during the combustion reaction is larger than that during the gasification reaction.

\subsection{Changes in Structure of Carbonaceous Matrix during Combustion and Gasification}

In order to clarify the reason why the size of ash particles increases under the combustion condition, porosity of the coke sample was measured. Figure 11 shows porosity of the raw coke sample and the coke samples (reaction ratio of $80 \%$ ) after combustion and gasification $\left(\mathrm{CO}: \mathrm{CO}_{2}=50: 50\right)$ at 1673 $\mathrm{K}$. The porosity of the coke sample after the combustion reaction was almost the same as that of the raw coke sample. However, the porosity of the coke sample was increased from approximately $31 \%$ to $40 \%$ by the gasification reaction. Furthermore, shrinkage ratios of coke samples during each reaction were measured. Figure 12 shows the shrinkage ratios of the coke samples during combustion and gasification $\left(\mathrm{CO}: \mathrm{CO}_{2}=50: 50\right)$ at $1673 \mathrm{~K}$. The shrinkage ratio of

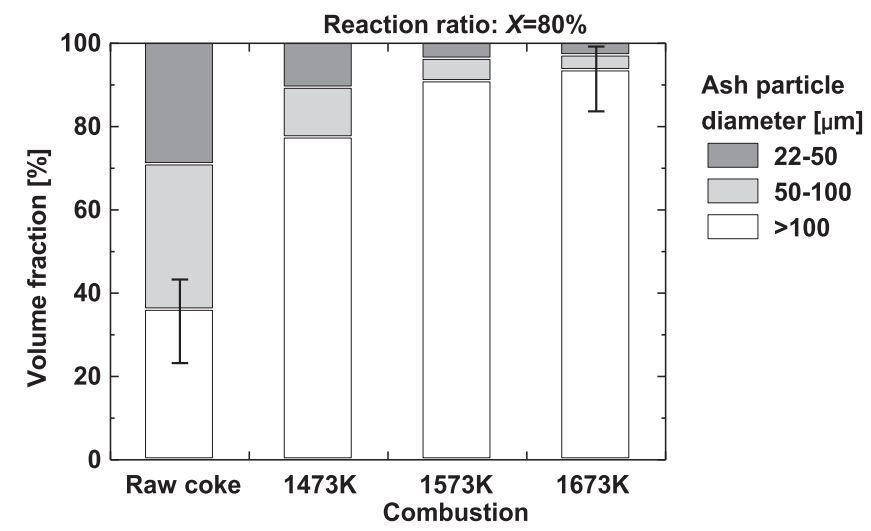

Fig. 9. Volume fraction of different-sized ash particles for the raw coke sample and the coke samples (reaction ratio of $80 \%$ ) for the combustion experiments at different temperatures.

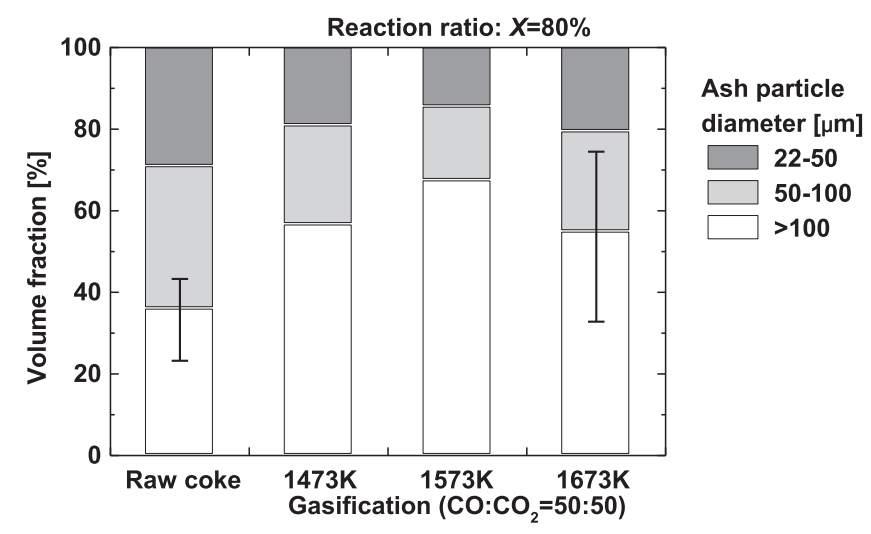

Fig. 10. Volume fraction of different-sized ash particles for the raw coke sample and the coke samples (reaction ratio of $80 \%)$ for the gasification experiments $\left(\mathrm{CO}: \mathrm{CO}_{2}=50: 50\right)$ at different temperatures. 


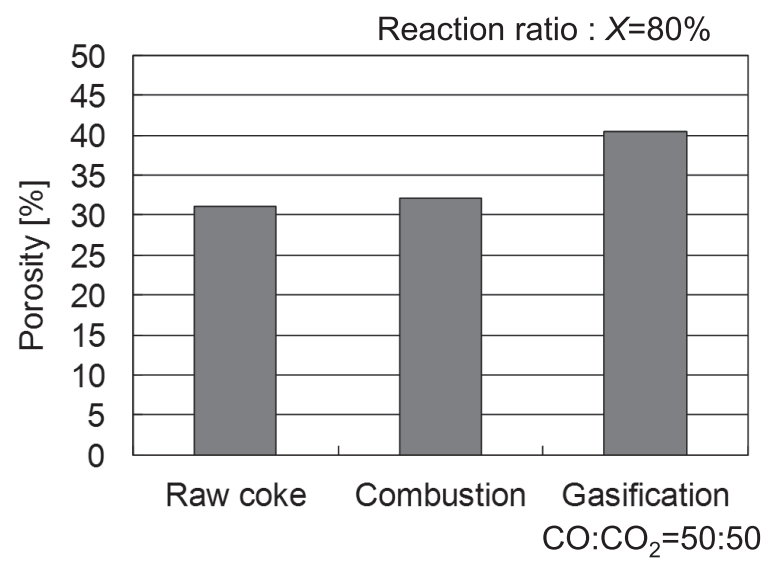

Fig. 11. Porosity of the raw coke sample and the coke samples (reaction ratio of $80 \%$ ) after combustion and gasification $\left(\mathrm{CO}: \mathrm{CO}_{2}=50: 50\right)$ at $1673 \mathrm{~K}$.

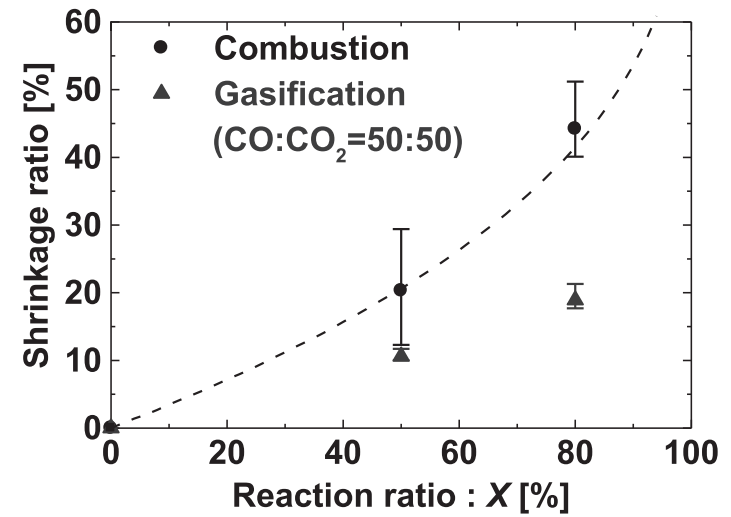

Fig. 12. Shrinkage ratio for the coke samples after combustion and gasification $\left(\mathrm{CO}: \mathrm{CO}_{2}=50: 50\right)$ at $1673 \mathrm{~K}$.

the coke sample during combustion was larger than that during gasification. These results suggest that the carbonaceous matrix is mostly consumed at the surface of the coke sample with the progress of combustion, whereas the carbonaceous matrix is consumed not only at the surface of the coke sample but also inside the coke sample with the progress of gasification. Therefore, making the assumptions that the reaction progressed only at the surface of the coke sample, and that the diameter decreased with the reaction, the shrinkage ratio of the coke sample during the reaction was estimated. The calculated shrinkage ratio is shown by a dashed line in Fig. 12. The fact that the shrinkage ratio during combustion almost corresponds with the calculated shrinkage ratio confirms that the combustion reaction of the coke sample under experimental conditions in this study occurs and the carbonaceous matrix is consumed at the coke surface.

The effects of the experimental temperature on porosity of the raw coke sample and the coke samples (reaction ratio of $80 \%)$ after combustion and gasification ( $\left.\mathrm{CO}: \mathrm{CO}_{2}=50: 50\right)$ are shown in Figs. 13 and 14, respectively. For the combustion reaction, the porosity of the coke sample at $1473 \mathrm{~K}$ is slightly larger than that of the raw coke, but the porosity of the coke samples at the other temperatures is the same as that of the raw coke. This result suggests that the combustion reaction also occurs inside the coke sample at $1473 \mathrm{~K}$. In contrast, for the gasification reaction, the porosity slightly decreases with an increase in the experimental temperature.

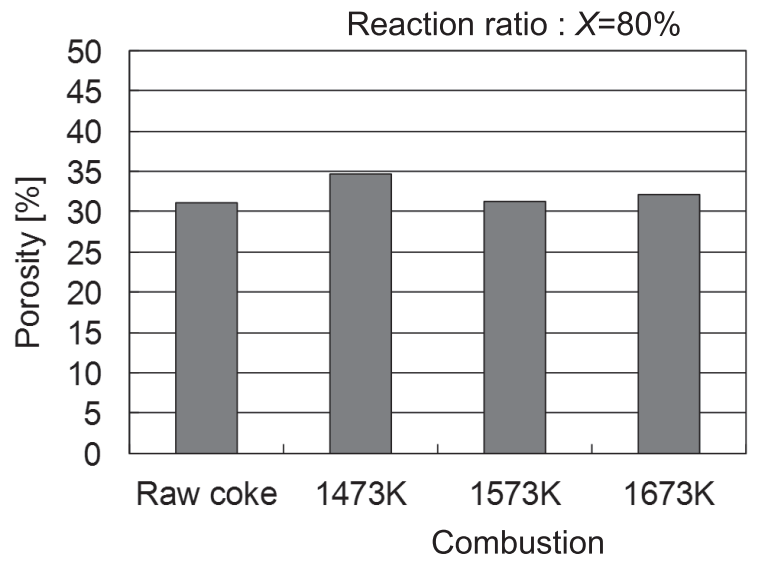

Fig. 13. Porosity of the raw coke sample and the coke samples (reaction ratio of $80 \%$ ) after the combustion experiments at different temperatures.

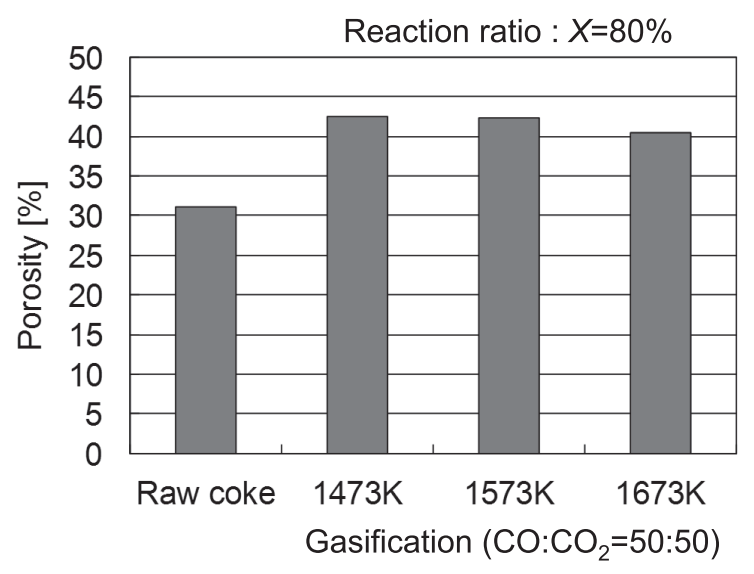

Fig. 14. Porosity of the raw coke sample and the coke samples (reaction ratio of $80 \%$ ) after the gasification experiments $\left(\mathrm{CO}: \mathrm{CO}_{2}=50: 50\right)$ at different temperatures.

From this, it is inferred that the consumption ratio of the carbonaceous matrix at the surface becomes higher due to the increase in temperature.

\subsection{Effect of Reaction Mechanism on Ash Particle Behaviors}

These results help in describing the behavior of ash particles during the combustion and gasification of coke. As for the results mentioned above, the coalescence of the ash particles during the combustion reaction is more marked than that during the gasification reaction. The combustion rate of coke at $1673 \mathrm{~K}$ is very high. ${ }^{27,28)}$ Accordingly, the combustion reaction occurs at the surface of the coke sample (surface reaction), where the carbonaceous matrix is consumed and the local temperature increases due to the heat of reaction from the combustion reaction (exothermic reaction). Ash particles at the surface of the coke sample melt and coalesce with neighboring ash particles, thus increasing the diameters of the ash particles near the surface of the coke. However, the gasification rate of coke at $1673 \mathrm{~K}$ is lower than the combustion rate at the same temperature. ${ }^{27,28)}$ Accordingly, the gasification reaction occurs also at the surface of the pore walls inside the coke sample (partial surface reaction). The carbonaceous matrix is also consumed inside the coke sample and exists around the ash particles. For this reason, it is dif- 
ficult for the molten ash particles to coalesce with each other. In this way, the behavior of the ash particles in the coke lump depends on the type of reaction taking place and is affected by the consumption mechanism of the carbonaceous matrix.

For the effect of the volume ratio of $\mathrm{CO}_{2}$ in atmospheric gas on the ash particle behavior during the gasification reaction, it is guessed that the consumption behavior of the carbonaceous matrix approaches that during the combustion reaction when the volume ratio of $\mathrm{CO}_{2}$ in atmospheric gas increases. Therefore, the volume fraction of ash particles with diameter more than $100 \mu \mathrm{m}$ increases with the increase in the volume ratio of $\mathrm{CO}_{2}$ in atmospheric gas. Furthermore, for the effect of the temperature on the ash particle behavior during both reactions, the consumption ratio of the carbonaceous matrix at the surface increases due to the increase in reaction rates. Also, the molten ash ratio increases when the experimental temperature increases. The coalescence of the ash particles is promoted by these effects.

\section{Conclusions}

The behavior of ash particles in coke lump samples during combustion and gasification were elucidated experimentally in this work. Combustion and gasification experiments on a single coke lump were conducted in atmospheres of air and $\mathrm{CO}-\mathrm{CO}_{2}$ mixture gas, respectively. The ash particles in the coke lump after the experiments were observed using an SEM. The following results were obtained:

(1) In the case of the combustion of the coke sample, larger ash particles, formed by the coalescence of molten ash particles, were observed on the surface of the coke sample after combustion. On the contrary, some molten spherical fine ash particles were observed inside the coke sample under the gasification condition, but the coke sample did not contain large molten ash particles.

(2) For the gasification reaction, the volume fraction of ash particles with diameter more than $100 \mu \mathrm{m}$ increased with the increase in the volume ratio of $\mathrm{CO}_{2}$ in atmospheric gas. As with the coke samples after the combustion reaction, the coalescence of ash particles in the coke samples occurs during the gasification reaction. However, the degree of progress of the ash particle coalescence during the gasification reaction is not as high as that during the combustion reaction.

(3) For both reactions, the volume fraction of larger ash particles increased due to the acceleration of coalescence of ash particles with an increase in the experimental temperature.

(4) The porosity of the coke sample after gasification was around $10 \%$ larger than that of the raw coke and the coke sample after combustion. In addition, the shrinkage ratio of the coke sample during combustion was larger than that during gasification. The combustion reaction occurs at the surface of the coke sample (surface reaction). The gasification reaction also occurs at the surface of the pore walls inside the coke sample (partial surface reaction).

(5) In the case of the partial surface reaction, it was difficult for the molten ash particles to coalesce with each other due to the existence of the carbonaceous matrix around the ash particles. The behavior of the ash particles in the coke lump depends on the type of reaction taking place and is affected by the consumption mechanism of the carbonaceous matrix.

\section{Acknowledgments}

This work was partially performed by a Research Group for Mechanisms and Control of Cohesive Zone Phenomena for Blast Furnace Permeability, in The Iron and Steel Institute of Japan (the chief examiner is Prof. H. Nogami, from Tohoku Univ.). The authors would like to acknowledge the contribution of all research group members. Additionally, this work was partially supported by the Steel Foundation for Environmental Protection Technology, the 21st JFE Foundation Century and JSPS KAKENHI Grant Number JP16K21089.

\section{REFERENCES}

1) T. Ariyama: Tetsu-to-Hagané, 105 (2019), 567 (in Japanese). https:// doi.org/10.2355/tetsutohagane.TETSU-2019-008

2) T. Ariyama and M. Sato: ISIJ Int., 46 (2006), 1736. https://doi. org/10.2355/isijinternational.46.1736

3) H. Bertling: ISIJ Int., 39 (1999), 617. https://doi.org/10.2355/ isijinternational.39.617

4) H. Nogami, Y. Ueki, T. Murakami and S. Ueda: Tetsu-toHagané, 100 (2014), 227 (in Japanese). https://doi.org/10.2355/ tetsutohagane.100.227

5) M. Hayashi, S. Sukenaga, K. Ohno, S. Ueda, K. Sunahara and N. Saito: Tetsu-to-Hagané, 100 (2014), 211 (in Japanese). https://doi. org/10.2355/tetsutohagane.100.211

6) S. Ueda, T. Miki, T. Murakami, H. Nogami and T. Sato: Tetsuto-Hagané, 99 (2013), 1 (in Japanese). https://doi.org/10.2355/ tetsutohagane.99.1

7) T. Ariyama, R. Murai, J. Ishii and M. Sato: ISIJ Int., 45 (2005), 1371. https://doi.org/10.2355/isijinternational.45.1371

8) K. Ohno, S. Tsurumaru, A. Babich, T. Maeda, D. Senk, H. W. Gudenau and K. Kunitomo: ISIJ Int., 55 (2015), 1245. https://doi. org/10.2355/isijinternational.55.1245

9) T. Matsui, N. Ishiwata, Y. Hara and K. Takeda: ISIJ Int., 44 (2004), 2105. https://doi.org/10.2355/isijinternational.44.2105

10) M. W. Chapman, B. J. Monaghan, S. A. Nightingale, J. G. Mathieson and R. J. Nightingale: ISIJ Int., 47 (2007), 973. https:// doi.org/10.2355/isijinternational.47.973

11) F. McCarthy, R. Khanna, V. Sahajwalla and N. Simento: ISIJ Int., 45 (2005), 1261. https://doi.org/10.2355/isijinternational.45.1261

12) F. McCarthy, V. Sahajwalla, J. Hart and N. Saha-Chaudhury: Metall. Mater. Trans. B, 34 (2003), 573.

13) M. Shin, J.-S. Oh and J. Lee: ISIJ Int., 55 (2015), 2056. https://doi. org/10.2355/isijinternational.ISIJINT-2015-115

14) C. S. Nguyen, K. Ohno, T. Maeda and K. Kunitomo: ISIJ Int., 56 (2016), 1325. https://doi.org/10.2355/isijinternational. ISIJINT-2015-739

15) T. Kon, S. Sukenaga and S. Ueda: ISIJ Int., 57 (2017), 1166. https:// doi.org/10.2355/isijinternational.ISIJINT-2017-008

16) K. Ohno, S. Miura, T. Maeda and K. Kunitomo: ISIJ Int., 59 (2019), 655. https://doi.org/10.2355/isijinternational.ISIJINT-2018-383

17) J.-K. Chung and N.-S. Hur: ISIJ Int., 37 (1997), 119. https://doi. org/10.2355/isijinternational.37.119

18) Y. Shen, T. Shiozawa, P. Austin and A. Yu: Miner. Eng., 63 (2014), 91.

19) S. V. Vassilev, K. Kitano, S. Takeda and T. Tsurue: Fuel Process. Technol., 45 (1995), 27.

20) G. P. Huffman, F. E. Huggins and G. R. Dunmyre: Fuel, 60 (1981), 585.

21) J.-R. Qiu, F. Li, Y. Zheng, C.-G. Zheng and H.-C. Zhou: Fuel, 78 (1999), 963

22) H. Liu, C. Luo, M. Toyota, S. Kato, S. Uemiya, T. Kojima and H. Tominaga: Fuel, 82 (2003), 523.

23) S. V. Vassilev, G. M. Eskenazy and C. G. Vassileva: Fuel Process. Technol., 72 (2001), 103.

24) X. Wu, Z. Zhang, G. Piao, X. He, Y. Chen, N. Kobayashi, S. Mori and Y. Itaya: Energy Fuels, 23 (2009), 2420.

25) R. Yoshiie, T. Tsuzuki, Y. Ueki, Y. Nunome, I. Naruse, N. Sato, T. Ito, Y. Matsuzawa and T. Suda: Proc. Combustion Institute, Vol. 34, The Combustion Institute, Pittsburgh, PA, (2013), 2895.

26) Y. Ueki, R. Yoshiie and I. Naruse: ISIJ Int., 55 (2015), 1305. https:// doi.org/10.2355/isijinternational.55.1305

27) N. M. Laurendeau: Prog. Energy Combust. Sci., 4 (1978), 221.

28) Y. Iwanaga and K. Takatani: ISIJ Int., 29 (1989), 43. https://doi. org/10.2355/isijinternational.29.43 